\title{
TERAPIA DE REPOSIÇÃO HORMONAL (TRH)
}

Nunca se viu tanta polêmica em torno de uma terapêutica como a constatada nos últimos tempos em relação à TRH no climatério. Frise-se que, muitas vezes, as discussões são apaixonadas, impedindo o encontro da verdade.

Inúmeras são as facções dos apaixonados. De fato, alguns proclamam somente benefícios, enquanto outros, apenas riscos. Há também aqueles que declinam somente efeitos colaterais ou, simplesmente, contraindicam a TRH para todas as mulheres.

Como-se vê, o panorama que se descortina é de um radicalismo absurdo.

A Medicina, e particularmente a Terapêutica, nunca deve se pautar por discussões de cunho pessoal, tendenciosas ou envolvendo outros interesses.

As opiniões podem divergir, mas devem ser pautadas pelo bom senso e com base nas evidências aceitáveis na literatura, preferencialmente decorrentes de estudos clínicos randomizados, envolvendo grande número de pacientes.

Assim, a literatura nos mostra adequadamente os pontos positivos e negativos da TRH e alguns serão citados a seguir.

Um dos pontos positivos é a boa resposta à TRH - em mulheres com sintomas desconfortáveis no climatério como ondas de calor, insônia e alterações cutâneo- mucosas. Do mesmo modo, é inquestionável o impacto benéfico, quer preventivo quer terapêutico sobre a osteoporose.

Estes mesmos esteróides, no entanto, propiciam riscos. Assim, o uso isolado do estrogênio (a depender do tipo, dose e duração do uso) pode elevar o risco do câncer endometrial. Este risco, porém, pode ser reduzido com o uso concomitante do progestógeno, pelo menos durante 12 ou 14 dias do mês.

Outro possível problema da TRH seria sua associação após dez anos de uso com incremento do risco para o câncer de mama. Contudo, deve ser ressaltado que os estudos epidemiológicos a respeito apresentam resultados conflitantes, com riscos relativos muito variáveis.

Mais recentemente, surgiu outro problema da TRH; este resultou do estudo HERS, em que se observou que a reposição hormonal combinada contínua, ou seja, a ministração da associação de estrogênios conjugados equinos $(0,625 \mathrm{mg})$ com acetato de medroxiprogesterona $(2,5 \mathrm{mg})$ não promove o tão propalado benefício quanto à prevenção secundária da doença coronariana, revelado pelos estudos observacionais.

Entretanto, é imperioso considerar que o HERS não apagou os inúmeros benefícios demonstrados por evidências muito boas sobre os sintomas e sobre a diminuição do risco de osteoporose.

A literatura mostra ainda outros pontos positivos sobre o risco do câncer de cólon, da degeneração macular e da doença periodontal; todos, no entanto, merecem confirmações.

Mudanças nos esquemas de tratamento, invocando baixas doses de esteróides, têm se multiplicado e invadido os periódicos de alto impacto; as evidências, no entanto, mostram benefícios, especificamente sobre os sintomas.

Por tudo isso, é fundamental que se individualize os casos; além do que não devem ser prescritas outras alternativas indiscriminadamente, como os fitoterápicos, que além de sua eficácia ainda questionável, podem promover riscos, como o constatado com o derivado sintético da soja - ipriflavona - responsável por linfocitopenia em 19\% de suas usuárias.

A obrigação dos médicos, portanto, é promover junto as suas pacientes um diálogo franco, claro e sem insinuações. Cabe ao profissional de saúde orientar o que representa a redução de hormônios no climatério e quais são os benefícios e riscos da TRH. A decisão deverá sempre ser da paciente. 